\title{
ADAPTASI DOKTRIN PROMISSORY ESTOPPEL DALAM PENYELESAIAN GANTI RUGI PADA TAHAP PRA KONTRAK PADA HUKUM KONTRAK DI INDONESIA Oleh
}

\author{
I Gde Prim Hadi Susetya \\ I Made Pasek Diantha \\ Putu Tuni Cakabawa Landra \\ Program Magister Kenotariatan Universitas Udayana \\ email : primhadi91@gmail.com/rasenshurikens@gmail.com
}

\begin{abstract}
ABSTRAK
Tahap pra kontraktual adalah merupakan tahap awal dari sebuah perundingan antara para pihak yang membuat. Dalam tahap ini bias disebut juga tahap negosiasi atau perundingan atau kesepahaman awal sebelum memasuki kontrak yang sebenarnya. Permasalahan hukum akan timbul jika sebelum perjanjian tersebut sah dan mengikat para pihak, yaitu dalam proses perundingan atau preliminary negotiation, salah satu pihak telah melakukan perbuatan hukum seperti meminjam uang, membeli tanah, padahal belum tercapai kesepakatan final antara mereka mengenai kontrak bisnis yang di rundingkan. Hal ini dapat terjadi karena salah satu pihak begitu percaya dan menaruh pengharapan terhadap janji-janji yang diberikan oleh rekan bisnisnya. Jika pada akhirnya perundingan mengalami jalan buntu dan tidak tercapai kesepakatan, misalnya tidak tercapai kesepakatan mengenai fees, royalties atau jangka waktu lisensi, maka tidak dapat di tuntut ganti rugi atas segala biaya, investasi yang telah dikeluarkan oleh rekan bisnisnya.

Berdasarkan permasalahan tersebut, maka permasalahan yang dapat diangkat dalam penelitian ini adalah (1) Bagaimana pengaturan penyelesaian ganti rugi menurut system hokum di Indonesia, dan (2) Bagaimanakah pengadaptasian Doktrin Promissory Estoppel dalam hukum kontrak di Indonesia.

Berangkat dari adanya kekosongan norma dimana tidak diaturnya akibat hokum pada tahap pra kontraktual baik dalam KUHPerdata maupun peraturan perundangundangan lainnya yang berkaitan dengan hukum kontrak, maka penelitian ini menggunakan penelitian hukum normatif. Penelitian ini menggunakan pendekatan perbandingan, pendekatan kasus dan pendekatan konseptual. Sumber bahan hukum dalam penelitian ini terdiri dari bahan hukum primer, sekunder dan tersier. Teknik pengumpulan bahan hukum dengan cara melakukan study kepustakaan. Teknik analisis bahan hukum yang digunakan adalah teknik deskriptif, teknik sistematis, dan teknik evaluatif.

Hasil penelitian ini menunjukkan bahwa (1) pengaturan penyelesaian ganti rugi belum diatur secara tegas dalam KUHPerdata maupun dalam peraturan perundangundangan lainnya yang berkaitan dengan kontrak. Dalam KUHPerdata, ganti rugi hanya diberikan jika terjadi wan perstasi dan perbuatan melawan hukum. Namun, jika salah satu pihak merasa dirugikan dalam tahap pra kontraktual bias menggugat ke pengadilan negeri. (2) Pengadaptasian doktrin hukum Promissory Estoppel ke dalam system hukum Indonesia bisa dilakukan karena adanya kesamaan system hukum di common law (inggris, amerika) denga system hukum di Indonesia, sehingga pengadilan di Indonesia bisa memakai doktrin tersebut untuk mengisi kekosongan hukum dalam hukum kontrak.
\end{abstract}

Kata Kunci: Doktrin Promissory Estoppel, Ganti Rugi, Tahap Pra Kontraktual.

\section{ABSTRACT}

Pre-contractual phase is an early phase of a negotiation of two-sided affairs. This phase can be also called as the early phase of negotiation or agreement or understanding before enters the actual contract agreement. Legal issues will arise, if before thecontract has not validand bind of the two-sided affairs yet, namely in the negotiation process or preliminary negotiation; one of the two-sided affairs has disobeyed 
the law legal actions such as borrow money, buy land, however, they have not reached the final agreement yet regarding the negotiated business contract. This case can be occurred because one of the parties obviously trusts and hopes in the promises which are given by another party. If, in the end, the final agreement is deadlocked and has no reached any deal at all, such as the agreement is unreachable regarding of fees, royalties or license terms, any expenses and the investments that has spent by his business partnerwill not be sued for the compensation.

Based on these problems, therefore the problems of study that can be appointed are (1) How does to set compensation arrangement setting based on the legal system in Indonesia and (2) How does to adapt the Doctrine of Promissory Estoppel in contract law in Indonesia.

Regarding there is no norm that enlisted the effects of law in pre-contractual phase either in the Civil Procedure Code or in any other legislation related to contract law; therefore, this study uses normative legal studies. This study uses a comparative, case studies and conceptual approaches. The sources of legal materials in the study consist of primary legal, secondary and tertiary materials. The collection method of the sources of legal materials is by conducting the library studies. The used analysis methods of legal materials are descriptive, systematic, and evaluative methods.

The results of the study indicated that (1) the compensation arrangement setting has not been regulated strictly either in the Civil Procedure Code or in any other legislation related to contract law. In the Civil Procedure Code, the compensation will be given only if wanperstasi (in form of breach of contract) and tort occur. However, if one of the parties feels aggrieved in the pre-contractual phase, it can sue to the District Court. (2) Adapting the legal doctrine of Promissory Estoppel into Indonesian legal system can be conducted because both of the legal system in common law (British and United States of America) and legal system in Indonesia have similarities, so that the courts in Indonesia can use the doctrine to fill the legal vacuum in contract law.

Keywords: The Doctrine of Promissory Estoppel, Compensation, Pre-Contractual Phase.

\section{Pendahuluan}

Penulisan penelitian ini dilandasi oleh permasalahan bagaimana penyelesaian ganti rugi pada tahap pra kontrak, dimana apabila salah satu pihak memberikan janjinya dan pihak menaruh percaya dan pengharapan kepada janji tersebut dan melakukan perbuatan hukum, kemudian disisi lain pihak pemberi janji menarik janjinya secara sepihak.

Fungsi kontrak, terutama dalam dunia bisnis, adalah untuk melindungi kepentingan para pihak dalam rangka mengatur hak dan kewajiban, sehingga tercipta kepastian hukum bagi para pihak yang membuatnya. Lazimnya dalam dunia bisnis, perjanjian dibuat secara tertulis, yakni dengan pembuatan kontrak. Sebelum memasuki kontrak, para pihak biasanya memasuki tahap pra kontak, yakni tahap dimana para pihak mempunyai suatu kesepahaman awal untuk memasuki suatu kontrak.
Permasalahan hukum akan timbul jika sebelum perjanjian tersebut sah dan mengikat para pihak, yaitu dalam proses perundingan atau preliminary negotiation, salah satu pihak telah melakukan perbuatan hukum seperti meminjam uang, membeli tanah, padahal belum tercapai kesepakatan final antara mereka mengenai kontrak bisnis yang di rundingkan. Hal ini dapat terjadi karena salah satu pihak begitu percaya dan menaruh pengharapan terhadap janji-janji yang diberikan oleh rekan bisnisnya. ${ }^{1}$ Jika pada akhirnya perundingan mengalami jalan buntu dan tidak tercapai kesepakatan, misalnya tidak tercapai kesepakatan mengenai fees, royalties atau jangka waktu lisensi, maka tidak dapat di tuntut ganti rugi atas segala biaya, investasi yang telah dikeluarkan oleh rekan bisnisnya. ${ }^{2}$

${ }^{1}$ Suharnoko, 2004, Hukum Perjanjian : Teori Dan Analisa Kasus, Cetakan Ke-1, Prenada Media Group, Jakarta, hal. 1

${ }^{2}$ Ibid. 
Tentunya pihak yang telah melakukan perbuatan hukum tersebut merasa dirugikan apabila perbuatannya tersebut adalah perbuatan yang dilakukan sebelum terjadinya kontrak yang final atau mengalami jalan buntu diantara para pihak yang melakukan perjanjian atau dengan kata lain salah satu pihak menarik janjijanji yang telah diucapkan yang mengakibatkan kerugian yang diderita oleh pihak lain.

Keadaan ini dimunculkan akibat adanya kekosongan norma (vacum of norm) dimana dalam Kitab Undang-Undang Hukum Perdata dan peraturan perundangundangan terkait dengan perjanjian atapun kontrak belum mengatur adanya akibat hukum janji-janji yang diberikan pada tahap pra kontrak.

Dalam sistem hukum di Indonesia yang menganut sistem hukum civil law belum diatur secara tegas mengenai akibat hukum dari perjanjian pada tahap pra kontrak. Apabila ada pihak yang mengalami kerugian dalam tahap pra kontrak dan mengajukan gugatan ke pengadilan, tentu saja gugatan tersebut akan kalah. Selama ini para hakim di Indonesia memutus perkara tidak hanya melihat dari kepastian hukum semata, melainkan dari sisi keadilan juga. Perjanjian pra kontrak dimata beberapa hakim Indonesia dianggap bukanlah suatu perjanjian yang sah karena tidak atau belum memiliki suatu hal tertentu yang diperjanjikan sehingga ganti kerugian atas wanprestasi terhadap perjanjian pra kontrak tidak dapat dimintakan. Pengadilan sebagai gerbang menuju keadilan, dimana orang-orang mencari keadilan harus bertindak secara adil kepada setiap warga Negara.

Tahap pra kontraktual adalah tahap di mana para pihak melakukan perundingan untuk menentukan isi perjanjian yang nantinya akan mereka sepakati. Kesepakatan ini merupakan salah satu syarat penting untuk menerbitkan hubungan hukum selain syarat-syarat lain seperti yang diatur dalam ketentuan Pasal 1320 KUHPerdata. Selain ketentuan Pasal 1320 KUHPerdata, dalam membuat perjanjian para pihak juga harus memperhatikan asas-asas dalam perjanjian. ${ }^{3}$

Di Negara-negara maju yang menganut common law system seperti Inggris dan Amerika Serikat, berdasarkan doktrin promissory estoppels atau detrimental reliance, janji-janji pada tahap pra kontrak bisa bisa dituntut ganti kerugian apabila ada pihak yang merasa dirugikan. Doktrin promissory estoppels ini adalah suatu doktrin hukum yang mencegah seseorang pemberi janji (promissor) untuk menarik kembali janjinya, dalam hal pihak yang menerima janji (promise) karena kepercayaannya terhadap janji tersebut telah melakukan sesuatu perbuatan atau tidak berbuat sesuatu, sehingga penerima janji akan menderita kerugian. ${ }^{4}$ Maka pada tahap negosiasi atau pra kontrak dapat dituntut ganti kerugian. Hal ini untuk melindungi pihak penerima janji yang telah melakukan atau tidak melakukan sesuatu perbuatan, sehingga akan mengalami kerugian apabila pihak pemberi janji menarik janjinya.

${ }^{3}$ Antari Innaka, 2013, "Penerapan Asas Itikad Baik Tahap Pra Kontraktual Pada Perjanjian Jual Beli Perumahan" Mimbar Hukum Bagian Hukum Perdata, Fakultas Hukum Universitas Gadjah Mada, Yogyakarta, Oktober 2012

${ }^{4}$ Bisdan Sigalingging, 2014, "Teori Tentang Perjanjian", Serial Online, (Cited 2016 may. 11), available from : URL : https://bisdansigalingging.blogspot.co.id/2014/10/teori-tentangperjanjian.html 
Berdasarkan uraian di atas, maka rumusan masalah dalam penelitian ini dapat dikemukakan dalam research question adalah (1) Bagaimana pengaturan penyelesaian ganti rugi dalam tahap pra kontrak menurut sistem hukum di Indonesia? dan (2) Bagaimana pengadaptasian Doktrin Promissory Estoppel dalam hukum kontrak di Indonesia?

\section{Metode Penelitian}

Penelitian ini merupakan penelitian hukum normatif yang beranjak dari kekosongan norma dimana dalam Kitab UndangUndang Hukum Perdata dan peraturan perundang-undangan terkait dengan perjanjian atapun kontrak belum mengatur adanya akibat hukum janji-janji yang diberikan pada tahap pra kontrak, sehingga bisa menimbulkan permasalahan hukum dan tentunya memberikan rasa tidak adil pada pihak yang merasa dirugikan karena tidak memiliki kekuatan hukum untuk menuntu ganti kerugian. Penelitian ini menggunakan pendekatan kasus, pendekatan analisis konsep hukum, dan pendekatan perbandingan. Sumber bahan hukum dalam penelitian ini terdiri dari bahan hukum primer, bahan hukum sekunder, dan bahan hukum tersier. Teknik pengumpulan bahan hukum dalam penelitian ini adalah dengan menggunakan telaah kepustakaan (study document). Teknik analisis bahan hukum menggunakan teknik deskriptif, evaluatif dan sistematis.

\section{TEORI DAN TINJAUAN UMUM TENTANG PRA KONTRAK, KONTRAK, DOKTRIN PROMISSORY ESTOPPEL, DAN SISTEM HUKUM COMMON LAW DAN CIVIL LAW}

\subsection{Teori Kontrak}

Teori Kontrak atau disebut juga dengan the contract theory, atau contract theorie, mempunyai arti yang sangat penting dalam kehidupan bermasyarakat, berbangsa dan bernegara. Hal ini disebabkan karena teori ini menganalisis hubungan hukum antara subyek hukum yang satu dengan subyek hukum yang lainnya.

David J. Mack menyajikan pengertian kontrak. A Contract is : "An Agreement between two or more parties that creates an obligation on all parties to perform (or not perform) a particular action or set of related action". Kontrak dalam definisi ini dikonstruksikan sebagai sebuah persetujuan antara dua pihak atau lebih untuk menciptakan kewajiban hukum semua pihak, yaitu untuk melakukan (atau tidak melakukan) tindakan tertentu atau serangkaian tindakan terkait. Unsur-unsur kontrak dalam definisi ini meliputi :

a. Adanya persetujuan;

b. Adanya para pihak atau subyek hukum;

c. Adanya kewajiban hukum dari semua pihak; dan

d. Melakukan atau tidak melakukan sesuatu

Sementara itu, objek kajian dari teori kontrak, yaitu :

a. Hubungan hukum para pihak;

b. Adanya subyek hukum;

Adanya hak dan kewajiban; ${ }^{5}$

\subsection{Teori Autonomy of Contract atau} Teori Kontrak Otonom

Autonomy of Contract theory atau teori kontrak otonom difokuskan pada pendekatan keadilan para pihak dalam suatu sengketa yang berkaitan dengan kontrak. Andrew S. Gold membagi teori kontrak otonom menjadi tiga macam, yaitu:

${ }^{5}$ Munir Fuady, op.cit, hal. 68 
a. Promissory theories;

b. Reliance theories; and

c. Transfer theories

Promissory

theories

merupakan teori yang menjelaskan tentang mengikatnya kontrak karena adanya persetujuan para pihak. Persetujuan merupakan komponen dasar dari kontrak. Persetujuan itu sebagai dasar di dalam melaksanakan hak dan kewajiban para pihak. Promissory theories dibangun atas dasar pendekatan moral. ${ }^{6}$

Reliance theories atau teori ketergantungan merupakan teori yang difokuskan pada kepentingan promisse. Promise, yaitu orang menerima tawaran dari penawar (promisor). Idenya, bahwa promisor meminta kepada promise untuk melaksanakan kewajiban kontraktualnya. Transfer theories atau teori transfer merupakan teori yang menganalisis tentang pelaksanaan kontrak, karena promise telah memperoleh hak-hak dari promisor. Ini berarti bahwa promise harus memindahkan atau melaksanakan kewajiban kontraktualnya.

\subsection{Teori Keadilan}

Teori

$$
\text { keadilan }
$$

ini

dikemukakan oleh Aristoteles. Keadilan adalah tindakan yang terletak diantara memberikan terlalu banyak dan sedikit yang dapat diartikan memberikan sesuatu kepada setiap orang sesuai dengan apa yang menjadi hak nya. ${ }^{7}$

Aristoteles membagi keadilan menjadi dua macam, yaitu :

1. Keadilan dalam arti umum;

2. Keadilan dalam arti khusus ${ }^{8}$

${ }^{6}$ Ibid.

${ }^{7}$ Asrur Rifa, 2016, "Teori Keadilan Menurut Aristoteles", Serial Online, (Cited 2016 may. 22), available from : URL

http://www.siswamaster.com/2016/01/teori-

keadilan-menurut-aristoteles-dancontoh.html?m=1

${ }^{8}$ Hans Kelsen, 2008, Dasar-Dasar Hukum Normatif, Nusa Media, Bandung, Hal. 146
Keadilan dalam arti umum adalah keadilan yang berlaku bagi semua orang. Tidak membedabedakan antara orang yang satu dengan yang lainnya. Justice for all. Keadilan dalam arti khusus merupakan keadilan yang berlaku hanya ditujukan pada orang tertentu saja (khusus). Disamping itu, aristoteles juga membagi keadilan menjadi dua macam, yaitu:

1. Keadilan distributif;

2. Keadilan korektif ${ }^{9}$

Keadilan

distributive dijalankan dalam distribusi kehormatan, kemakmuran, dan aset-aset lain yang dapat dibagi dari komunitas yang bisa dialokasikan diantara para anggotanya secara merata atau tidak merata oleh legislator. Prinsip keadilan distributif adalah kesetaraan yang proporsional (seimbang). Keadilan korektif merupakan keadilan yang menyediakan prinsip korektif dalam transaksi privat. Keadilan korektif dijalankan oleh hakim dalam menyelesaikan perselisihan dan member hukuman terhadap pelaku kejahatan. ${ }^{10}$

\subsection{Teori 3P}

Teori ini didasarkan kepada pemilikiran Scoott J. Burham yang mendasarkan dalam penyusunan suatu kontrak haruslah dimulai mendasari dengan pemikiran-pemikiran sebagai berikut :

a. Predictable, dalam perancangan dan analisa kontrak seorang darfter harus dapat meramalkan atau melakukan prediksi mengenai kemungkinankemungkinan apa yang akan terjadi yang ada kaitannya dengan kontrak yang disusun.

b. Provider, yaitu siap-siap terhadap kemungkinan yang akan terjadi.

c. Protect of Law, perlindungan hukum terhadap kontrak yang telah

${ }^{9}$ Ibid., hal. 146-148

${ }^{10}$ Salim HS, op.cit, hal. 27-28 
dirancang dan dianalisa sehingga dapat melindungi klien atau pelaku bisinis dari kemungkinankemungkinan terburuk dalam menjalankan bisnis. ${ }^{11}$

3.5 Tinjauan Umum Tentang Pra Kontrak, Kontrak, Doktrin Promissory Estoppel, Dan Sistem Hukum Common Law Dan Civil Law

\subsubsection{Pengertian Pra Kontrak}

Tahap pra kontrak merupakan tahap sebelum kontrak dirancang dan disusun. Dalam Black Law Dictionary pengertian pra kontrak adalah:

"Precontractual is a contract that precludes a party from entering into comparable agreement with someone else."

Dalam masyarakat pengusaha (bisnis) tahap pra kontraktual sering disamakan dengan Memorandum of Understandings (MoU) sebelum masuk atau mengikatkan diri ke dalam kontrak yang mengikat. Memorandum of Understandings (MOU) atau nota kesepahaman adalah pernyataan tertulis yang merincikan kesepahaman awal dari pihakpihak yang akan mengikatkan diri ke dalam suatu kontrak atau perjanjian lainnya. ${ }^{12}$

Sebelum kontrak disusun, ada empat hal yang harus diperhatikan oleh para pihak. Keempat hal itu meliputi: identifikasi para pihak, penelitian awal aspek terkait, pembuatan Memorandum of Understanding (Mou), dan negosiasi.

1. Identifikasi Para Pihak

Tahap identifikasi para pihak merupakan tahap untuk menentukan dan menetapkan

${ }^{11}$ M. Yusrizal, 2011, “Teori Dalam Hukum Kontrak", Serial Online, (Cited 2014 okt. 24), available from : URL : http://myrizal76.blogspot.com/2011/03/teori-dalam-hukumkontrak.html

${ }^{12}$ Rosa Agustina, op.cit, hal. 87 identitas para pihak yang akan mengadakan kontrak. Identitas para pihak harus jelas dan para pihak harus mempunyai kewenangan hukum untuk membuat kontrak. Orang yang berwenang membuat kontrak adalah orang yang sudah dewasa dan/atau sudah kawin. Ukuran kedewasaan adalah telah berumur 21 tahun. Orang yang tidak berwenang untuk melakukan perbuatan hukum adalah:

a. Anak dibawah umur (minderjarigheid)

b. Orang yang ditaruh dibawah pengampuan.

c. Istri (Pasal 1330 KUHPerdata). Akan tetapi, dalam perkembangannya istri dapat melakukan perbuatan hukum sebagaimana yang diatur dalam pasal 31 Undang-Undang Nomor 1 Tahun 1974 Jo. SEMA No. 3 Tahun 1963.

Dalam Pasal 39 UndangUndang No. 2 Tahun 2014 Tentang Perubahan Atas Undang-Undang No. 30 Tahun 2004 Tentang Jabatan Notaris ditentukan dua syarat bagi para pihak yang menghadap ke Notaris, yaitu paling sedikit berumur 18 Tahun atau telah menikah dan cakap melakukan perbuatan hukum.

2. Penelitian awal aspek terkait

Pada dasarnya, pihak-pihak berharap bahwa kontrak yang ditandatangani dapat menampung semua keinginannya sehingga apa yang menjadi hakikat kontrak benar-benar terperinci secara jelas. Perancangan kontrak harus menjelaskan hal-hal yang tertuang dalam kontrak yang bersangkutan, konsekuensi yuridis, serta alternatif lain yang mungkin dapat dilakukan. Pada akhirnya penyusunan kontrak menyimpulkan hak dan kewajiban masing-masing pihak, memperhatikan hal terkait dengan isi kontrak, seperti unsur 
pembayaran, ganti rugi, serta perpajakan. ${ }^{13}$

3. Pembuatan Memorandum of

Understanding (MoU)

Istilah Memorandum of

Understanding berasal dari dua kata, yaitu memorandum dan understanding. Secara gramatikal memorandum of understanding diartikan sebagai nota kesepahaman. Dalam Black Law Dictionary, yang diartikan memorandum adalah:

"is to serve as the basis of future formal contract." Yang terjemahannya ke dalam bahasa Indonesia adalah "dasar untuk memulai penyusunan kontrak secara formal pada masa datang."

Sedangkan understanding diartikan sebagai:

"An implied agreement resulting from the express term of another agreement, whether written or oral." Artinya, pernyataan persetujuan secara tidak langsung terhadap hubungannya dengan persetujuan lain, baik secara lisan maupun secara tertulis."

Munir Fuady, mengartikan Memorandum of Understanding sebagai berikut:

"Perjanjian pendahuluan, dalam arti nantinya akan diikuti dan dijabarkan dalam perjanjian lain yang mengaturnya secara detail, karena itu, memorandum of understanding berisikan hal-hal yang pokok saja. Adapun mengenai lain-lain aspek dari memorandum of understanding relatif sama dengan perjanjianperjanjian lain." 14

\subsubsection{Pengertian Kontrak}

Perjanjian dapat dilakukan secara lisan dan dapat dilakukan secara tertulis. Perjanjian lisan pada umumnya dilakukan di

${ }^{13}$ Salim HS, op.cit, hal. 86

${ }^{14}$ Munir Fuady, 1997, Hukum Bisnis dalam Teori Dan Praktik, Buku Ke-4, Citra Aditya Bhakti, Bandung, hal. 91 masyarakat adat untuk ikatan hukum yang sederhana, misalnya perjanjian "pengkadasan ternak", perjanjian "nyakap tanah". Sedangkan perjanjian, pada umumnya dilakukan pada masyarakat yang relatif sudah modern, berkaitan dengan bisnis yang hubungan hukumnya kompleks. Perjanjian tertulis untuk hubungan bisnis itu disebut dengan kontrak. ${ }^{15}$

Istilah kontrak berasal dari bahasa Inggris, yaitu contracts. Sedangkan dalam bahasa Belanda, disebut dengan overeenkomst (perjanjian). Pengertian perjnajian atau kontrak diatur Pasal 1313 KUHPerdata. Pasal 1313 KUHPerdata berbunyi:

"Perjanjian adalah suatu perbuatan dengan mana satu pihak atau lebih mengikatkan dirinya terhadap satu orang atau lebih."

Di dalam Black's Law Dictionary, yang diartikan dengan kontrak adalah:

"An agreement between two or more person which creates an obligation to do or not to do particular thing".

Artinya, kontrak adalah suatu persetujuan antara dua orang atau lebih, dimana menimbulkan sebuah kewajiban untuk melakukan atau tidak melakukan sesuatu secara sebagian. Inti definisi yang tercantum dalam Black's Law Dictionary bahwa kontrak dilihat sebagai persetujuan dari para pihak untuk melaksanakan kewajiban, baik melakukan atau tidak melakukan secara sebagian.

Charles L. Knapp dan Nathan M. Crystal mengatakan, contract is:

${ }^{15}$ I Ketut Artadi dan I Dewa Nyoman Rai Asmara Putra, 2010, Implementasi KetentuanKetentuan Hukum Perjanjian Ke Dalam Perancangan Kontrak, Udayana University Press, Denpasar, hal. 28 
"An Agreement between two or more persons not merely a shared belief, but common understanding as to something that is to be done in the future by one or both of them.",16

\subsubsection{Sumber Hukum Kontrak}

Pada dasarnya sumber hukum kontrak dapat dibedakan menurut system hukum yang mengaturnya. Sumber hukum, dapat dilihat dari keluarga hukumnya. Ada keluarga hukum romawi, common law, hukum sosialis, hukum agama, dan hukum tradisional. Disini penulis akan menyajikan sumber hukum kontrak berdasarka system hukum romawi atau civil law dan common law.

1. Sumber hukum kontrak dalam civil law (Indonesia)

Pada dasarnya sumber hukum dapat dibedakan menjadi dua macam, yaitu sumber hukum materiil dan sumber hukum formal.

Sumber hukum materiil ialah tempat darimana materi hukum itu diambil. Sumber hukum materiil ini merupakan faktor yang membantu pembentukan hukum, misalnya hubungan social, kekuatan politik, situasi sosial ekonomi, tradisi, hasil penelitian ilmiah, perkembangan internasional, dan keadaan geografis. ${ }^{17}$ Sumber hukum formal merupakan tempat memperoleh kekuatan hukum. Ini berkaitan dengan bentuk atau cara yag menyebabkan peraturan hukum formal itu berlaku. ${ }^{18}$

Sumber hukum kontrak yang berasal dari undang-undang merupakan sumber hukum yang berasal dari peraturan perundang-

${ }^{16}$ Charles L. Knapp dan Nathan M. Crystal, 1993, Problems in Contract Law Case and Materials, Little, Brown and Company, Boston Toronto London, hal. 2

${ }^{17}$ Chainur Arrasjid, 2014, Dasar-Dasar Ilmu Hukum, Cetakan Ke-6, Sinar Grafika, Jakarta, hal. 48

${ }^{18}$ Ibid, hal. 50 undangan yang dibuat oleh pemerintah dengan persetujuan DPR. Sumber hukum kontrak yang berasal dari peraturan perundangundangan adalah sebagai berikut:

a. Algemene Bepalingen van Wetgeving (AB)

b. Buku Ke III KUHPerdata

c. KUHDagang

d. Undang-Undang Nomor 5 Tahun 1999 Tentang Larangan Praktik Monopoli dan Persaingan Usaha Tidak Sehat.

e. Undang-Undang Nomor 18 Tahun 1999 Tentang Jasa Konstruksi

f. Undang-Undang Nomor 30 Tahun 1999 Tentang Arbitrase dan Alternatif Pilihan Penyelesaian Sengketa

g. Undang-Undang Nomor 24 Tahun 2000 Tentang perjanjian Internasional

2. Sumber Hukum Kontrak Common Law (Amerika)

Dalam hukum kontrak Amerika (common law), sumber hukum dibagi menjadi dua kategori, yaitu sumber hukum primer dan sekunder. Sumber hukum primer merupakan sumber hukum yang utama. Para pengacara dan hakim menganggap bahwa sumber primer dianggap sebagai hukum itu sendiri. Sumber hukum primer meliputi putusan pengadilan (judicial opinion), statuta, dan peraturan lainnya. Sumber hukum sekunder merupakan sumber hukum yang kedua. Sumber hukum ini mempunyai pengaruh dalam pengadilan, karena pengadilan dapat mengacu pada sumber hukum tersebut. ${ }^{19}$

Berdasarkan sumber tersebut, maka sumber hukum kontrak yang berlaku di Amerika Serikat dibedakan menjadi 4 macam, yaitu judicial opinion, statutory law, the restatement, dan legal commentary.

${ }^{19}$ Salim HS, op.cit, hal. 17 


\section{a. Judicial Opinion}

Judicial Opinion atau disebut juga dengan judge made law atau judicial decision merupakan sumber primer hukum kontrak. Judicial opinion merupakan pernyataan atau pendapat, atau putusan para hakim di dalam memustuskan perkara atau kasus, apakah kasus pidana atau perdata. Seperti kita ketahui bahwa sistem pengadilan Amerika dalam pembuatan keputusan, biasanya dinyatakan sebagai stare decisis, ketaatan terhadap keputusan yang telah lewat atau disebut precedents. Preseden adalah keputusan yang terdahulu yang fakta-fakta cukup mirip dengan kasus sub judice yang berada dibawah keputusan pengadilan (adjudication).

b. Statutory Law (Hukum Perundangundangan)

Sumber lain dari hukum kontrak adalah bersumber dari statutory of law (hukum perundang-undangan). Sumber hukum ini melengkapi hukum kebiasaan (common law). Statutory of law merupakan sumber hukum yang tertulis. ${ }^{20}$

c. Restatement

Restatement merupakan hasil rumusan ulang tentang hukum. Rumusan ini dilakukan karena timbulnya ketidakpastian dan kurangnya keseragaman dalam hukum dagang (commercial law). Restatement tersebut menyerupai undang-undang, meliputi black letter, penyataan-pernyataan dari "aturan umum" (atau kasus itu mengetengahkan konflik dengan aturan yang lebih baik).

d. Legal Commentary (Komentar Hukum)

Legal commentary merupakan sumber hukum sekunder. Legal commentary dianalogkan dengan doktrin dalam hukum continental karena commentary of law merupakan pendapat atau ajaranajaran dari para pakar tentang hukum kontrak.

Pada dasarnya yang banyak dikomentari oleh para pakar hukum kontrak adalah tentang restatement kontrak. Restatement kontrak telah mempunyai dampak yang kuat dalam membentuk pandangan pengadilan tentang apa yang sepatutnya dilakukan common law dari kontrak. Restatement tentang kontrak cukup mempunyai pengaruh kuat dalam hukum. Akan tetapi, selama bertahun-tahun telah bermacam artikel dipublikasikan, buku-buku, dan beraneka ragam risalah telah dicurahkan untuk menganalisis, mengevaluasi, dan mempersatukan badan-badan yang luas tentang kasus-kasus kontrak yang telah diakumulasi dalam keputusan yang dilaporkan oleh pengadilan Amerika.

\subsubsection{Syarat Sahnya Kontrak}

Sesuai dengan ketentuan dalam Pasal 1320 KUHPerdata, untuk sahnya suatu kontrak atau perjanjian diperlukan, 4 (empat) syarat, yakni:

1. Sepakat mereka yang mengikatkan dirinya;

2. Kecakapan untuk membuat suatu perikatan;

3. Suatu hal tertentu;

4. Suatu sebab yang halal;

Pasal 1320 KUHPerdata ini merupakan pasal yang sangat popular karena menerangkan tentang syarat yang harus dipenuhi untuk lahirnya suatu perjanjian. Syarat tersebut baik mengenai pihak yang membuat perjanjian atau biasa disebut syarat subyektif maupun syarat mengenai perjanjian itu sendiri (isi perjanjian) atau biasa disebut dengan syarat objektif. ${ }^{21}$

${ }^{21}$ Ahmadi Miru dan Sakka Pati, 2013, Hukum Perikatan: Penjelasan Makna Pasal 1233 


\subsubsection{Unsur-Unsur Perjanjian atau Kontrak}

a. Unsur Esensialia

Unsur esensialia adalah unsur yang harus ada dalam perjanjian, tanpa adanya unsur esensialia maka tidak ada perjanjian. Unsur esensialia dalam perjanjian mewakili ketentuan-ketentuan berupa prestasi-prestasi yang wajib dilakukan oleh salah satu atau lebih pihak, yang mencerminkan sifat dari perjanjian tersebut, yang membedakannya secara prinsip dari jenis perjanjian lainnya. ${ }^{22}$ Contohnya dalam perjanjian jual beli harus ada kesepakatan mengenai barang dan harga karena tanpa kesepakatan mengenai barang dan harga dalam perjanjian jual beli, perjanjian tersebut batal demi hukum karena tidak ada hal tertentu yang diperjanjikan. ${ }^{23}$

b. Unsur Naturalia

Unsur naturalia merupakan unsur yang telah diatur dalam undang-undang sehingga apabila tidak diatur oleh para pihak dalam kontrak, undang-undang yang mengaturnya. Dengan demikian, unsur naturalia ini merupakan unsur yang selalu dianggap ada dalam kontrak. Sebagai contoh, jika dalam kontrak tidak diperjanjikan tentang cacat tersembunyi, secara otomatis berlaku ketentuan dalam KUHPerdata bahwa penjual yang harus menanggung cacat tersembunyi. ${ }^{24}$

c. Unsur Aksidentalia

Unsur aksidentalia merupakan unsur yang nanti ada atau mengikat para pihak jika para

Sampai 1456 BW, Cetakan Ke-5, PT. Raja Grafindo Persada, Jakarta, hal. 67

${ }^{22}$ Kartini Muljadi dan Gunawan Widjaja, 2014, Perikatan Yang Lahir Dari Perjanjian, Cetakan Ke-6, PT. Raja Grafindo Persada, Jakarta, hal. 85

${ }^{23}$ R. Soeroso, 2011, Perjanjian Di Bawah Tangan, Sinar Grafika, Jakarta, hal. 17

${ }^{24}$ Ahmadi Miru, op.cit, hal 31-32 pihak memperjanjikannya. Bisa dikatakan bahwa unsur aksidentalia merupakan unsur pelengkap dalam suatu perjanjian, yang merupakan ketentuanketentuan yang dapat diatur secara menyimpang oleh para pihak, sesuai denga kehendak para pihak, yang merupakan persyaratan khusus yang ditentukan secara bersama-sama oleh para pihak. ${ }^{25}$ Sebagai contoh, dalam kontrak jual beli dengan angsuran diperjanjikan bahwa apabila pihak debitur lalai membayar utangnya, dikenakan denda $2 \%$ per bulan keterlambatan, dan apabila debitur lalai membayar selama tiga bulan berturut-turut, barang yang sudah dibeli dapat ditarik kembali oleh kreditor tanpa melalui pengadilan. ${ }^{26}$

\subsubsection{Jenis-Jenis Kontrak}

Para ahli dibidang kontrak tidak ada kesatuan pandangan tentang pembagian jenis-jenis kontrak. Ada ahli yang mengkajinya dari sumber hukumnya, namanya, bentuknya, aspek kewajibannya, maupun aspek larangannya.

1. Kontrak Menurut Sumber Hukumnya

2. Kontrak menurut namanya

3. Kontrak menurut bentuknya

4. Kontrak Sepihak dan Timbal Balik

5. Perjanjian cuma-cuma dan atas beban

6. Perjanjian berdasarkan sifatnya

\subsection{Tinjauan Umum Tentang} Doktrin Promissory Estoppel

Doktrin promissory estoppel ini merupakan doktrin yang berkembang di system hukum common law, yakni di Negara Inggris dan Amerika Serikat. Kata estoppel merupakan bagian terpenting dari doktrin tersebut. Estoppel diambil dari kata estop yang oleh oxford dictionary disebut stop up. Dalam Black Law

\footnotetext{
${ }^{25}$ Kartini Muljadi dan Gunawan Widjaja, op.cit, hal. 89

${ }^{26}$ Ibid.
} 
Dictionay, konsep estoppel ini diartikan sebagai:

1. A bar that prevents one from asserting a claim or right that contradicts what one has said or done before or what has been legally established as true.

2. A bar that prevents the relitigation of issues.

3. An affirmative defence alleging good-faith reliance on a misleading representation and an injury or detrimental change in position resulting from that reliance. Waiver.

Charles YC Chew dalam bukunya yang berjudul Business Law: Guidebook, menyebutkan ada unsur-unsur agar doktrin promissory estoppel tersebut agar dapat berlaku, diantaranya:

1. A representation must be made;

2. The representation must be cler, whether expressed or implied; and

3. The party relying on the representation must be placed at material disadvantage because that representation has not been honoured. $^{27}$

Konsep estoppel ini pada dasarnya adalah hukum pembuktian dimana seseorang dilarang menyangkal bukti yang sudah terbukti secara tegas dan nyata dalam persidangan. Estoppel berhubungan erat dengan surat permohonan pelepasan tuntutan.

\subsection{Tinjauan Umum Tentang} Civil Law dan Common Law

\subsubsection{Civil Law System}

Sistem hukum ini berkembang terutama di Eropa daratan, sehingga kerap kali juga disebut "Sistem Hukum Eropa Kontinental." 28 Istilah civil law sendiri berasal dari bahasa latin yakni ius civile, yaitu hukum yang berlaku bagi para cives (warga negara), atau resminya ius civile quiritium, yaitu hukum yang berlaku bagi para warga negara penuh Romawi, dan membedakan diri dari hukum alam (ius naturale) dan hukum internasional (ius gentium).

Dalam perkembangannya civil law dapat memiliki tiga pengertian sebagai berikut:

a. Sebagai hukum sipil (perdata) atau hukum umum, sebagai cabang dari hukum positif yang tidak memuat kaidah-kaidah pidana.

b. Sebagai sistem yurisprudensi yang berlaku dan dilaksanakan dalam sistem hukum romawi; dan

c. Sebagai hukum sipil yang merupakan bagian dari hukum continental eropa yang secara luas mencakup kaidah-kaidah hukum perdata. $^{29}$

\subsubsection{Common Law System}

Sistem common law secara orisinil berkembang dibawah pengaruh sistem yang bersifat adversarial dalam sejarah inggris berdasarkan keputusan pengadilan yang berdasarkan tradisi, custom, dan preseden. Bentuk reasoning yang digunakan dalam common law dikenal dengan casuistry atau case based reasoning. Common law dapat juga berbentuk hukum tak tertulis maupun hukum tertulis seperti tertuaang dalam statute atau codes. ${ }^{30}$

Istilah common law berasal dari bahasa prancis "communeley" yang merujuk kepada adat kebiasaan (custom) di Inggris yang tak tertulis dan yang melalui keputusan-keputusan hakim

${ }^{27}$ Charles YC Chew, 2008, Business Law: Guide Book, Oxford University Press, Australia, page. 45

${ }^{28}$ Anonim, 2016, "Sistem Hukum di Dunia", Serial Online, (diakses 19 Juni 2016), available from : URL https://id.wikipedia.org/wiki/Sistem_hukum_di_d unia

$$
\text { URL }
$$

${ }^{29}$ Budiono Kusumohamidjojo, 2015, Perbandingan Hukum Kontrak (Comparative Contract Law), CV. Mandar Maju, Bandung, hal. 26-27

${ }^{30}$ Ade Maman Suherman, 2012, Pengantar Perbandingan Sistem Hukum: Civil Law, Common Law, Hukum Islam, PT Raja Grafindo Persada, Jakarta, hal. 75 
dijadikan berkekuatan hukum. Common law adalah hukum kebiasaan atau asas-asas tidak tertulis yang sudah menjadi dasar dari putusan-putusan pengadilan serta sudah lama diterima dalam perilaku manusia. Kebiasaan dan asas-asas dalam common law berasal dari case law, yang sudah lama diterima sehingga menjadi preseden. Case law adalah kumpulan putusan-putusan pengadilan yang lebih tinggi tingkatannya yang harus diikuti oleh hakim-hakim yang lebih rendah tingkatannya dalam memutus perkara serupa, dalam kenyataan, case law yang sudah menjadi presen sering disebut juga common law. ${ }^{31}$

\section{PENGATURAN}

PENYELESAIAN GANTI RUGI PADA TAHAP PRA KONTRAK MENURUT SISTEM HUKUM DI INDONESIA

4.1 Penyelesaian Ganti Rugi Menurut Kitab Undang-Undang Hukum Perdata

Dalam KUHPerdata yang dianut oleh sistem hukum di Indonesia, tidak diatur secara tegas mengenai ganti kerugian pada tahap pra kontrak dan tahapan-tahapan dalam membuat kontrak. Pasal 1320 KUHPerdata sendiri hanya mengatur mengenai syarat sahnya kontrak atau perjanjian. KUHPerdata hanya melihat ganti rugi bisa dituntut jika terjadi wanprestasi dan perbuatan melawan hukum.

\subsubsection{Ganti Rugi Berdasarkan Wan Prestasi}

Terjadinya wanprestasi senantiasa diawali dengan hubungan kontraktual (characteristic of default is always preceded by a contractual relationship). Kontrak dibuat sebagai instrument yang secara

${ }^{31}$ E. Sundari, op.cit, hal, 22-23 khusus mengatur hubungan hukum antara kepentingan yang bersifat privat dan perdata khususnya dalam pembuatan kontrak.

Wanprestasi atau dikenal dengan istilah ingkar janji, yaitu kewajiban dari debitur untuk memenuhi suatu prestasi, jika dalam melaksanakan kewajiban bukan terpengaruh karena keadaan, maka debitur dianggap telah melakukan ingkar janji. Kata wanprestasi berasal dari bahasa belanda, yaitu berarti prestasi buruk.

Dengan adanya wanprestasi, pihak yang dirugikan akibat kegagalan pelaksanaan prestasi mempunyai hak gugat dalam upaya menegakkan hak-hak kontrak atau perjanjiannya. Hal ini sebagaimana telah diatur dalam Pasal 1267 KUHPerdata yang menyataka bahwa:

"Pihak yang terhadapnya perikatan tidak dipenuhi, dapat memilih untuk memaksa pihak lain untuk memenuhi perjanjian, jika hal itu masih dapat dilakukan, atau menuntut pembatalan perjanjian, dengan penggantian biaya, kerugian dan bunga".

Hak-hak gugat dapat diajukan secara tersendiri maupun dikombinasikan dengan gugatan lain, meliputi:

1. Pemenuhan (nakoming);

2. Ganti Rugi (vervangende vergoeding);

3. Pembubaran, pemutusan, atau pembatalan (ontbinding); ${ }^{32}$

\subsubsection{Ganti Rugi Berdasarkan Perbuatan Hukum}

Perbuatan melawan hukum dalam KUHPerdata diatur dalam Pasal 1365 hingga Pasal 1380. Meskipun pengaturan perbuatan melawan hukum dalam KUHPerdata hanya 15 pasal,

${ }^{32}$ Agus Yudha Hernoko, 2008, Hukum Perjanjian Asas Proporsionalitas Dalam Kontrak Komersial, Laksbang Mediatama, Jogjakarta, hal. 235 
tetapi kenyataan menunjukkan bahwa gugatan perdata di pengadilan didominasi oleh gugatan perbuatan melawan hukum disamping gugatan wanprestasi. ${ }^{33}$

Perbuatan melawan hukum di Indonesia secara normatif selalu merujuk pada ketentuan Pasal 1365 KUHPerdata. Rumusan norma pada pasal ini unik, tidak seperti ketentuan-ketentuan pasal lainnya. Perumusan norma Pasal 1365 KUHPerdata lebih merupakan struktur norma daripada substansi ketentuan hukum yang sudah lengkap. ${ }^{34}$

Dalam hal ganti rugi pada tahap pra kontrak bisa dituntut ganti kerugian sebab disni terjadi hubungan sebab akibat yang menimbulkan kerugian di salah satu pihak yang percaya dengan janji-janji pihak lainnya. Hubungan sebab akibat merupakan faktor yang mengaitkan antara kerugian seseorang dengan perbuatan orang lain. Dengan demikian timbul pertanyaan, kapankah dapat dikatakan bahwa suatu kerugian adalah fakta (the fact) atau kemungkinan/kira-kira (proximate) dan kapan pula dianggap terlalu jauh.

\subsection{Penyelesaian Ganti Rugi} Pada Tahap Pra Kontrak Melalui Jalur Pengadilan

Permasalahan atau sengketa antara para pihak sering kali muncul ketika para pihak telah berada dalam tahap pelaksanaan kontrak tersebut, namun tak jarang sengketa itu muncul ketika para pihak masih berada dalam tahap pra kontrak/negosiasi (pra contractual). Para pihak sering kali tidak mencapai kata sepakat atau kesulitan mencapai kata sepakat dalam tahap pra kontrak

${ }^{33}$ Rosa Agustina, 2012, Hukum Perikatan: Law of Obligations, Pustaka Larasan, Denpasar, hal. 3

${ }^{34}$ Ibid. atau bahkan slah satu pihak sudah menderita kerugian saat tahap pra kontrak.

Pada prinsipnya penegakan hukum hanya dilakukan oleh kekuasaan kehakiman (judicial Power) yang secara konstitusional lazim disebut badan yudikatif (Pasal 24 UUD 1945). Dengan demikian, maka yang berwenang memeriksa dan mengadili sengketa hanya badan peradilan yang bernaung di bawah kekuasaan kehakiman yang berpuncak di Mahkamah Agung. Pasal 2 UU No. 14 Tahun 1970 secara tegas menyatakan bahwa yang berwenang dan berfungsi melaksanakan peradilan hanya badan-badan peradilan yang dibentuk berdasarkan undangundang. Diluar itu tidak dibenarkan karena tidak memenuhi syarat formal dan official serta bertentangan dengan prinsip under the authority of law.

Apabila seseorang atau suatu badan hukum "merasa" dan "dirasa" bahwa haknya telah dilanggar oleh orang lain, kemudia penyelesaian damai secara kekeluargaan tidak tercapai, salah satu jalan dapat ditempuh oleh mereka adalah perkara tersebut diajukan kepada Hakim/Pengadilan Negeri berwenang, yaitu dengan dibuatnya surat gugatan perdata (burgelijk vordering, civil suit). ${ }^{35}$

Menurut

Sudikno

Mertokusumo yang dimaksud dengan surat gugatan adalah tuntutan hak sebagai tindakan yang bertujuan memperoleh perlindungan yang diberikan oleh pengadilan untuk mencegah

${ }^{35} \mathrm{H}$. Mohammad Saleh dan Lilik Mulyadi, 2012, Bunga Rampai Hukum Acara Perdata Indonesia: Perspektif, Teoritis, Praktik dan Permasalahannya, PT. Alumni, Bandung, hal. 37 
eigenrichting. ${ }^{36}$

Apabila

berdasarkan ketentuan Bab I Pasal

1 angka 2 Rancangan UndangUndang (RUU) Hukum Acara Perdata selaku "Future Law" kemudian hari merumuskan gugatan sebagai tuntutan hak yang mengandung sengketa dan diajukan ke pengadilan untuk mendapatkan putusan.

Darwan Prinst menyebutkan gugatan adalah suatu permohonan yang disampaikan kepada Ketua Pengadilan Negeri yang berwenang, mengenai suatu tuntutan terhadap pihak lainnya, dan harus diperiksa menurut tata cara tertentu oleh pengadilan, serta kemudian diambil putusan terhadap gugatan tersebut. ${ }^{37}$

Sengketa antara para pihak atau pihak yang merasa dirugikan dapat menuntut hak dan/atau ganti kerugian kepada Pengadilan Negeri setempat. Berdasarkan Pasal 118 ayat (1) Het Herziene Indonesisch Reglement (selanjutnya disebut HIR) menyatakan bahwa:

"Tuntutan (gugatan) perdata pada tingkat pertama termasuk lingkup wewenang pengadilan negeri, harus diajukan dengan surat permintaan (surat gugatan) yan ditandatangai oleh penggugat, atau oleh wakilnya menurut Pasal 123, kepada Ketua Pengadilan Negeri ditempat diam si tergugat, atau jika tempat diamnya tidak diketahui, kepada Ketua Pengadilan Negeri di tempat tinggalnya yang sebenarnya."

Tuntutan hak yang didalam Pasal 118 ayat (1) HIR, Pasal 142 ayat 1 Rechtsreglemet Buitengewesten (Selanjutnya disebut RBg) disebut sebagai

${ }^{36}$ Sudikno Mertokusumo, 1993, Hukum Acara Perdata Indonesia, Liberty, Jogjakarta, hal. 2

${ }^{37}$ Darwan Prinst, 2002, Strategi Menyusun dan Menangani Gugatan Perdata, PT. Citra Aditya Bakti, Bandung, hal. 2 tuntutan perdata (burgerlijke vordering) tidak lain adalah tuntutan hak yang mengandung sengketa dan lazimnya disebut gugatan. Gugatan dapat diajukan baik secara tertulis maupun secara lisan. ${ }^{38}$

\section{PENGADAPTASIAN DOKTRIN PROMISSORY ESTOPPEL DALAM HUKUM KONTRAK DI INDONESIA}

\subsection{Pengaturan Akibat Hukum Pada Tahap Pra Kontrak Sesuai Dengan Doktrin Promissory Estoppel}

Proses diterimanya lembaga atau aturan hukum asing ke dalam sistem hukum suatu Negara disebut dengan transpalantasi atau adaptasi hukum, yang diartikan sebagai perpindahan suatu aturan atau sistem hukum atau bagian dari sistem hukum dari suatu negara ke negara lain, atau dari suatu bangsa ke bangsa lain. ${ }^{39}$ Istilah yang menjelaskan terjadinya perpindahan atau peniruan atau pengoperan atau diterapkannya suatu aturan, sub atau sub-sub sistem hukum tersebut beragam. Ada yang mengistilahkan dengan transposisi hukum, ada yang mengistilahkan adopsi hukum, resepsi hukum, pengoperan hukum. ${ }^{40}$

Adaptasi hukum dewasa ini dapat dikatakan sudah merupakan fenomena di banyak negara. Sacco bahkan mengklaim bahwa inovasi hukum yang orisinil tanpa melakukan peminjaman atau peniruan hukum asing sangat kecil jumlahnya. Dalam era globalisasi terutama, tidak dapat dipungkiri terjadinya kerja sama antar negara, baik yang bersifat

\footnotetext{
${ }^{38}$ Sudikno Mertokusumo, op.cit, hal. 53
}

${ }^{39}$ Alan Watson, 1993, Legal Transplant an Approach to Comparative Law, Second Edition, The University of Georgia Press, Anthens \& London, hal. 21

${ }^{40}$ E. Sundari, op.cit, hal. 27 
bilateral atau multilateral. Hubungan-hubungan internasional dalam rangka memenuhi kebutuhan tersebut pada umumnya akan dituangkan dalam bentukbentuk hukum.

Sesuai dengan apa yang dijelaskan diatas bahwa adopsi atau adaptasi hukum dapat terjadi karena ada kemiripan atau kesamaan antara dua sistem hukum sehingga dapat bertemu. Dengan kata lain apabila doktrin promissory estoppels yang berasal dari sistem hukum common law bisa diadaptasi atau diadopsi oleh Indonesia yang menganut sistem hukum civil law, maka harus dicari persamaan diantara sistem hukum common law dan civil law dalam hal hukum kontrak.

\subsection{Penyelesaian Ganti Rugi Pada Tahap Pra Kontrak Dengan Adanya Doktrin Promissory Estoppel}

Terkait dengan sengketa pra kontrak yang terjadi antara para pihak dimana peraturan perundang-undangan di Indonesia khususnya KUHPerdata dan peraturan perundang-undangan yang terkait dengan kontrak belum mengatur mengenai akibat hukum terhadap janji-janji pra kontrak, maka apabila terjadi sengketa di tahap negosiasi, hakim bisa melakukan metode penafsiran hukum atau juga bisa melakukan penemuan hukum sehingga bisa mengisi kekosongan hukum untuk bisa menyelesaikan sengketa tersebut.

Dalam mengisi kekosongan hukum terhadap sengketa pra kontrak yang terjadi, hakim bisa melakukan studi perbandingan hukum yakni dengan melakukan studi kasus pra kontrak yang terjadi di negara lain seperti kasus pra kontrak yang terjadi negara common law, Inggris dan Amerika Serikat.
Sebagai contoh kasus pra kontrak yang terjadi di Inggris, dalam kasus London Property Trust Ltd melawan High Tress House Ltd (1947). Pada tahun 1937 penggugat menyewakan a block of flates di London kepada tergugat untuk jangka waktu 99 tahun dengan harga 2500 poundsterling per tahun. Ketika terjadi perang, sangat sulit bagi tergugat untuk mencari penghuni yang bersedia tinggal di flats tersebut sehingga penggugat setuju untuk menurunkan harga menjadi 1250 poundsterling selama waktu perang. Setelah selesai perang, penggugat menuntut supaya tergugat membayar penuh uang sewa untuk seluruh periode sewa. Pengadilan memutuskan bahwa janji penggugat untuk mengurangi uang sewa tersebut adalah mengikat meskipun janji tersebut diberikan tanpa consideration dari penyewa, karena berdasarkan doktrin promissory estoppels, suatu janji mengikat meskipun diberikan tanpa considerations. ${ }^{41}$

Pengadilan di Amerika Serikat mengembangkan doktrin promissory estoppel untuk mengatasi situasi dimana perjanjian belum memenuhi syarat hal tertentu, tetapi salah satu pihak karena percaya dan menaruh pengharapan kepada janji-janji yang diberikan pihak lawannya dalam proses negosiasi, melakukan perbuatan seperti melakukan investasi. Ternyata kemudian pihak yang memberi janji menarik kembali janjinya sehingga salah satu pihak menderita kerugian.

Pengadilan memberikan penggugat reliance damages berupa ganti rugi atas kerugian yang nyata dan bukan expectation damages yaitu kehilangan

${ }^{41}$ Suharnoko, op.cit, hal 13-14 
keuntungan yang diharapkan. Penggugat tidak menerima expectation damages karena memang belum ada kontrak antara penggugat dan tergugat. Reliance loss dilindungi oleh doktrin promissory estoppel. ${ }^{42}$ Dengan demikian doktrin promissory estoppels yang semula merupakan tanggapan atas kekakuan penerapan doktrin consideration dan diterapkan hanya dalam hubungan kontraktual, kini diterapkan juga bagi janji-janji pra kontrak untuk melindungi reliance loss. ${ }^{43}$

\section{Kesimpulan dan Saran}

\subsection{Kesimpulan}

Dari pemaparan yang telah disampaikan pada bab-bab sebelumnya, maka penulis dapat menarik suatu kesimpulan dari penelitian tesis ini, yaitu:

1. Pengaturan penyelesaian ganti rugi pada tahap pra kontrak menurut sistem hukum di Indonesia belum diatur secara tegas dalam peraturan perundang-undangan yang berlaku di Indonesia. KUHPerdata sebagai aturan khusus yang mengatur hubungan perdata atau perjanjian, juga belum mengatur tentang penyelesaian ganti kerugian pada tahap pra kontrak juga akibat hukum tahap pra kontrak tersebut. KUHPerdata hanya mengatur akibat hukum setelah kontrak tersebut berjalan yakni wan prestasi, perbuatan melawan hukum dan force mejeur. Belum ada 1 (satu) ketentuan dalam KUHperdata yang mengatur tentang pra kontraktaul.

2. Tahap pra kontraktual merupakan tahap yang penting sebelum para pihak membuat kontrak yang sebenarnya. Para pihak dalam tahap ini juga perlu di berikan perlindungan jikalau ada sengketa. Dengan adanya doktrin Promissory Estoppel, para

${ }^{42}$ Donald Harris and Denis Tallon, 1989, Contract Law Today: Anglo-French Comparison, Clarendon Press, Oxford, London, page. 27

${ }^{43}$ Suharnoko, op.cit, hal. 16 pihak yang merasa dirugikan bisa menuntut haknya melalui pengadilan dan mendapat ganti kerugian atas kerugian yang nyata (reliance loss). Dengan demikian, pengadilan sebagai tempat untuk mencari keadilan bisa menjunjung tinggi rasa keadilan itu.

\subsection{Saran}

Adapun saran yang dapat penulis sampaikan terkait dengan permasalahan yang diteliti dalam penelitian ini adalah sebagai berikut:

1. Kepada Pemerintah serta DPR sebagai legislatif, sudah semestinya Kitab Undang-Undang Hukum Perdata tersebut di rubah isinya, terkait dengan kontrak dan asas itikad baik. NBW Belanda sendiri sudah menerapkan asas itikad baik sejak tahap pra kontraktual, sehingga sengketa kontrak bisa diminimalisir dan juga untuk melindungi para pihak. Terkait dengan syarat sahnya kontrak atau perjanjian, perlu kiranya ditambahkan adanya tahap negosiasi (penawaran dan penerimaan). Kata sepakat sendiri tidak serta merta muncul diantara para pihak yang membuat kontrak, tentunya mereka pasti melakukan penawaran dan permintaan.

2. Kepada penegak hukum, khususnya Pengadilan dalam menghadapi sengketa pra kontrak, bisa melakukan adopsi hukum terhadap doktrin promissory estoppel tersebut untuk menyelesaikan sengketa secara adil. 


\section{DAFTAR PUSTAKA}

Abdul Ghofur Anshori, 2009, Lembaga Kenotariatan Indonesia, Perspektif Hukum dan Etika. UII Press, Yogyakarta

Abdulkadir Muhammad, 2001, Etika Profesi Hukum. PT. Citra Aditya Bakti, Bandung

Habib Adjie, 2008, Hukum Notaris Indonesia: Tafsir Tematik terhadap UU No. 30 Tahun 2004 tentang Jabatan Notaris, Alumni, Bandung

Muhammad Ilham Arisaputra, 2012, Kewajiban Notaris Dalam Menjaga Kerahasiaan Akta Dalam Kaitannya dengan Hak Ingkar Notaris, Jurnal Perspektif, Vol. XVII No. 3, Edisi September 2012

Mukti Fajar ND dan Yulianto Achmad, 2010, Dualisme Penelitian Hukum Normatif dan Empiris, Pustaka Pelajar, Yogyakarta

Munir Fuady, 2006, Teori Hukum Pembuktian (Pidana dan Perdata), Citra Aditnya Bakti, Bandung

Peter Mahmud Marzuki, 2011, Penelitian Hukum, Prenada Media Grup, Jakarta

Purwoto Ganda Subrata, 2005, Peranan Notaris Sebagai Pejabat Umum Di Dalam Mengisi dan Turut Mensukseskan Pembangunan Nasional di Bidang Hukum, Renungan Hukum

R. Soesilo, 1995, Kitab Undang-Undang Hukum Pidana: Serta Komentarkomentarnya Lengkap Pasal Demi Pasal, Politeia, Bogor

Ranuhandoko, 2003, Terminologi Hukum, Grafika, Jakarta

Sigid Riyanto, 2015, Tindak Pidana Tertentu Yang Terkait Dengan Notaris dan PPAT, Magister Kenotariatan Universitas Gadjah Mada, Yogyakarta

Syafran Sofyan, 2015, Perlindungan Hukum Profesi PPAT-Notaris, Makalah pada Seminar Nasional: Perlindungan Hukum Terhadap Notaris Lampu Merah Oleh Majelis Kehormatan Notaris di Magister Kenotariatan FH Universitas Diponegoro 6 Juni 2015, Semarang 